\title{
ДОСЛІДЖЕННЯ ДИНАМІКИ ФІНАНСУВАННЯ ПРОГРАМ ІМУНОПРОФІЛАКТИКИ В УКРАÏHI
}

\author{
๑І. О. Федяк, І. І. Іванюлик \\ Івано-Франківський національний медичний університет
}

\begin{abstract}
Резюме: 2015 рік - рік завершення реалізації Загальнодержавної програми імунопрофілактики та захисту населення від інфекційних хвороб на 2009-2015 рр. Метою прийняття Програми було забезпечення епідемічного благополуччя населення шляхом зниження рівня захворюваності на інфекції, боротьба 3 якими проводиться засобами імунопрофілактики. Однак об'єктивні та суб'єктивні причини політико-економічних реалей сьогодення вже призвели до того, що Програма не виконується. Стан її реалізації у частині фінансування та, відповідно, охоплення щепленнями дитячого населення України на початок останнього року дії навіть не сягає рівня 50 \%. У статті представлено динаміку як фінансування системи охорони здоров'я України загалом, так і Програми імунопрофілактики зокрема, а також відсотка охоплення щепленнями дітей за період реалізації як чинної, так попередньої Програми імунопрофілактики.
\end{abstract}

Ключові слова: програма імунопрофілактики, обсяг фінансування системи охорони здоров'я України, відсоток охоплення щепленням населення.

Вступ. Всесвітня організація охорони здоров'я (ВООЗ) стурбована неякісною вакцинацією дітей в Україні, що є, за визначенням ВООЗ, «питанням національної безпеки». Після підписання коаліційної угоди між основними політичними партіями, які пройшли до Верховної ради України VIII скликання, представники ВООЗ та ЮНІСЕФ вітали «включення в коаліційну угоду умов закупівлі вакцин спільно з міжнародними партнерами та організаціями і підтвердили свою готовність здійснювати закупівлю та сприяти їй у відповідь на відповідний запит Міністерства охорони здоров'я України (МОЗ), для того, щоб врятувати життя і надати доступ до вакцинації дітям України» $[15,17,18]$. Однак узгоджені зміни у системі державних закупівель лікарських засобів (ЛЗ) загалом і вакцин зокрема не знайшли подальший розвиток у проектах змін до Бюджетного кодексу та Державному бюджеті на 2015 рік і, відповідно, станом на 01.03.2015 року не були прийняті. Загальний стан фінансування системи охорони здоров'я (ОЗ) та Програми імунопрофілактики як її складової не відповідають вимогам ВОО3. Це вже знайшло негативне відображення на рівні охоплення населення профілактичними щепленнями уже сьогодні та, як прогнозують експерти ВООЗ та вітчизняні аналітики, відобразиться на рівні загальної інфекційної захворюваності у недалекому майбутньому [5].

Питанням фінансування закупівлі ліків за державними цільовими програмами «Туберкульоз», «СНІД», «Онкологія» та «Дитяча онкологія» були присвячені статті і галузеві методичні рекомендації, виконані під керівництвом професора А. С. Немченко [13], пропозиції до удосконалення методології фармакоекономічних та маркетингових досліджень вакцинопрофілактики були знайдені у працях професорів А. А. Котвіцької та 3. М. Мнушко [11]. А метою нашої роботи став аналіз динаміки показників, які характеризують стан імунопрофілактики за бюджетні кошти в Україні, а саме: частки видатків на ОЗ, обсягів реального фінансування заходів з імунопрофілактики, рівня охоплення профілактичними щепленнями населення України.

Методи дослідження: бібліографічний, аналітичний, системно-логічний.

Результати й обговорення. Відповідно до Календаря профілактичних щеплень в Україні [12], 10 інфекційних хвороб, а саме: дифтерія, кашлюк, кір, краснуха, епідемічний паротит, поліомієліт, правець, туберкульоз, гемофільна інфекція, гепатит В підлягають обов'язковому запобіганню шляхом профілактичних щеплень. Вакцини проти цих хвороб відповідно до закону України № 1645-14 «Про захист населення від інфекційних хвороб» (поточна редакція від 05.12.2012 за законом № 5460-17) [3] закуповуються централізовано на єдиному державному тендері, який проводить МОЗ. У Законі зокрема сказано: «Поставки медичних імунобіологічних препаратів для проведення профілактичних щеплень, включених до календаря щеплень, здійснюються за рахунок коштів Державного бюджету України, а для проведення щеплень за епі-

ISSN 2312-0967. Фармацевтичний часопис. 2015. № 1 
демічними показаннями - за рахунок коштів місцевих бюджетів, а також інших джерел, не заборонених законодавством. Порядок забезпечення закладів ОЗ медичними імунобіологічними препаратами встановлюється центральним органом виконавчої влади, що забезпечує формування державної політики у сфері ОЗ».

Тому нами за доступними джерелами літератури [19] було проведено опрацювання динаміки витрат на ОЗ загалом з Державного бюджету України за період 2003 - 2013 років (рис. 1).

Отже, як свідчать дані, наведені на рисунку 1, відсоток видатків з бюджету на фінансування ОЗ відносно ВВП не зазнав значних відхилень і у середньому складає 3,7 \%, що є вкрай низьким і не досягає до рекомендованого мінімуму ВООЗ. Але при розрахунку сукупних ресурсних можливостей національної системи О3, необхідно враховувати також суми інших витрат: населення на придбання Л3; лікарняних кас; на приватну медицину; фінансування Світового банку і Глобального фонду боротьби з туберкульозом, ВІЛ/СНІДом та малярією; фондів допомоги хворим, діяльність яких фінансується неурядовими організаціями і благодійними фондами. А також левова частка фінансування ОЗ стосується неформальних (неофіційних) платежів за надання послуг. Тому всі сукупні видатки в ОЗ експерти оцінюють у $6-6,7 \%$ ВВП, а за деякими джерелами обсяг особистих витрат населення становить 3 - 3,5 \% ВВП, тобто практично рівний сукупним державним видаткам на ОЗ $[14,16]$.

Однак це не стосується фінансування системи імунопрофілактики. На даний час завер- шується виконання чинної Загальнодержавної програми імунопрофілактики та захисту населення від інфекційних хвороб на 2009-2015 роки (надалі Програма), яка була прийнята Законом України від 21.10.2009 р. № 1658-VI. Цій Програмі передувала Програма імунопрофілактики населення на 2002-2006 роки, затверджена Постановою КМУ від 24.10.2002 р. № 1566 [2].

У передмові до діючої Програми сказано: «Виконання попередньої Програми дало змогу знизити за період 2002-2006 років показники розповсюдженості інфекцій, що визначені пріоритетними Європейським регіональним бюро ВООЗ у програмному документі «Здоров'я-XXI: основи політики досягнення здоров'я для всіх у Європейському регіоні ВООЗ», зокрема дифтерії - 3 0,58 до 0,21; кору - $з$ 34,61 до 5,08; краснухи - з 161,87 до 47,24; епідемічного паротиту - з 47,87 до 8,02 на 100 тис. населення. Державна підтримка та допомога міжнародних організацій сприяли охопленню населення України щепленням проти кору на 98, 8 , дифтерії - 98,7\%, кашлюку, поліомієліту, туберкульозу (серед новонароджених) - на 97,8 \% (рекомендований ВООЗ показник - 95 відсотків)» [2].

Однак у звітах Рахункової палати цифри щодо відсотка охоплення щепленнями населення не такі оптимістичні. Тому нами був проведений детальний аналіз доступних звітів Рахункової палати, представлений у таблиці 1.

Як сказано у Конституції України, регулярні звіти про доходи і видатки Державного бюджету України мають бути оприлюднені. Контроль від імені Верховної Ради України (ВР) за надходженням коштів до Державного бюджету України

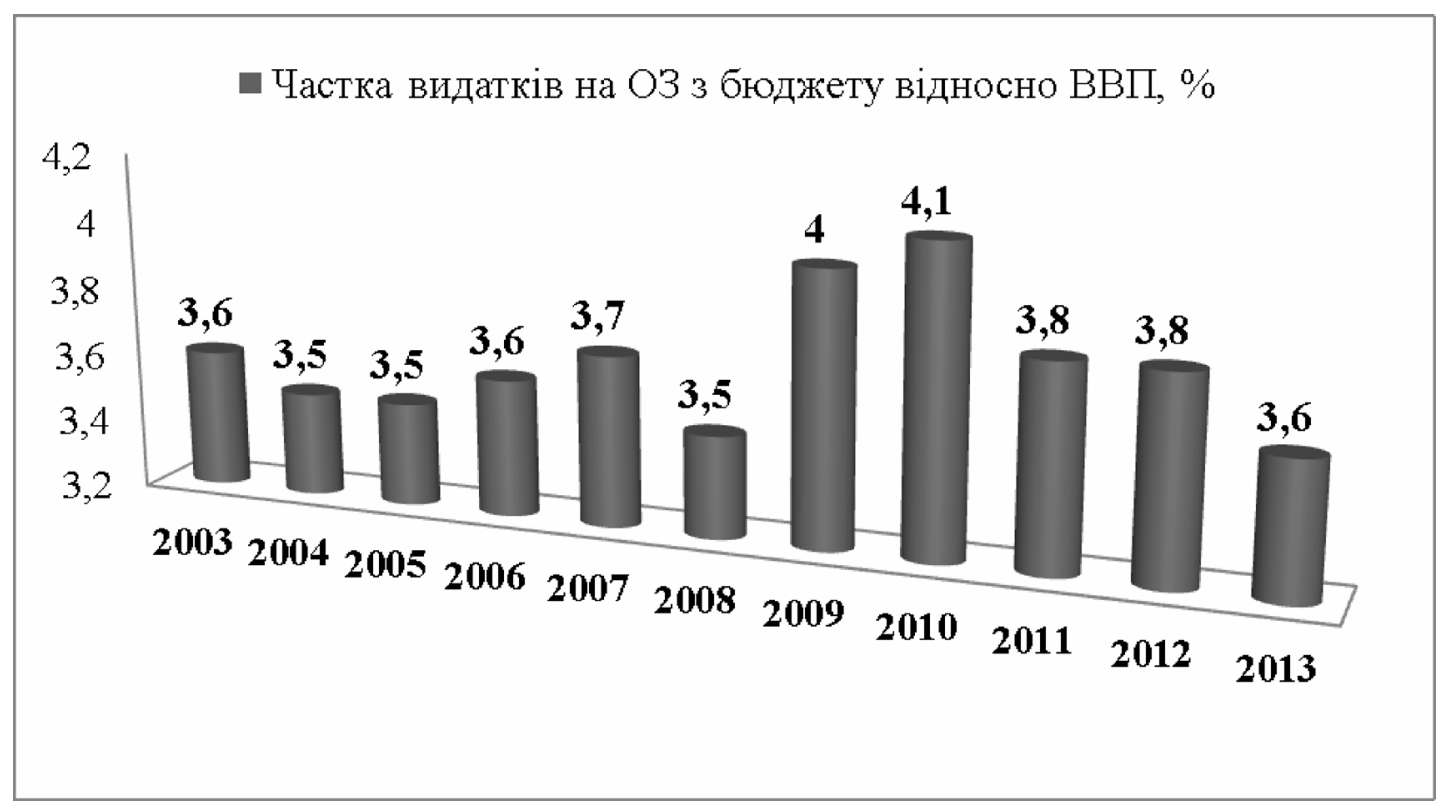

Рис. 1. Частка видатків на ОЗ з бюджету України відносно валового внутрішнього продукту (ВВП) (\%).

ISSN 2312-0967. Pharmaceutical review. 2015. № 1 
Організація роботи аптечних підприємств

Organization of pharmaceutical structures' work

Таблиця 1. Висновки Аудитів Рахункової палати щодо використання коштів Державного бюджету для забезпечення імунопрофілактики населення

\begin{tabular}{|c|c|}
\hline Рік & Результати \\
\hline $\begin{array}{c}2007 \\
{[6]}\end{array}$ & $\begin{array}{l}\text { Аудитом засвідчено, що МОЗ не забезпечено умови для сталого зниження захворюваності на } \\
\text { інфекційні хвороби, керовані специфічними засобами імунопрофілактики. Через неякісну підготовку } \\
\text { МОЗ проекту Загальнодержавної цільової програми імунопрофілактики і захисту населення від } \\
\text { інфекційних хвороб на 2007-2015 роки, станом на 01.04.2008 р. вказана програма не затверджена. } \\
\text { Таким чином, МОЗ не забезпечено виконання вимог законодавства, завдань ВР і Уряду щодо } \\
\text { запровадження програмно-цільового методу формування бюджетних видатків на ОЗ відповідно до } \\
\text { Бюджетного кодексу та Закону України «Про державні цільові програми». Діяльність галузі та } \\
\text { використання бюджетних коштів на імунопрофілактику є неефективними, оскільки показники стану } \\
\text { здоров’я населення України, пов’ язаного з інфекційними хворобами, суттєво не поліпшуються. Отже, } \\
\text { основна мета державних цільових програм з імунопрофілактики населення не досягнута. На виконання } \\
\text { бюджетної програми «Програми і централізовані заходи з імунопрофілактики» у } 2007 \text { році надійшло } \\
\text { коштів із загального фонду державного бюджету у сумі } 203,8 \text { млн грн або } 99 \text { \% затверджених } \\
\text { призначень, які повністю використані. За відсутності контролю з боку Міністерства фінансів за } \\
\text { використанням бюджетних коштів на централізовані заходи з імунопрофілактики, МОЗ з порушенням } \\
\text { чинного законодавства та неефективно використані кошти державного бюджету в сумі 123,4 млн грн } \\
\text { або 60,6 \% загальних обсягів фінансування, у тому числі з бюджетним правопорушенням - } \\
96,4 \text { млн грн, неефективно - 25,6 млн грн, завдано збитків на 1,6 млн грн. }\end{array}$ \\
\hline $\begin{array}{c}2008 \\
{[7]}\end{array}$ & $\begin{array}{l}\text { МO3 не забезпечено ефективне використання коштів Державного бюджету, виділених на виконання } \\
\text { заходів з імунопрофілактики населення. Управління бюджетними ресурсами здійснювалося } 3 \\
\text { порушеннями чинного законодавства. }\end{array}$ \\
\hline 2009 & $\begin{array}{l}\text { Не представлено інформацію про результати аудиту використання коштів державного бюджету, } \\
\text { виділених МОЗ на виконання заходів з імунопрофілактики населення. }\end{array}$ \\
\hline $\begin{array}{c}2010 \\
{[8]}\end{array}$ & $\begin{array}{l}\text { Аудит ефективності використання коштів Держбюджету, виділених МОЗ, засвідчив недосконалість } \\
\text { більшості діючих державних цільових програм, на виконання яких держава протягом значного часу } \\
\text { спрямовувала бюджетні кошти. Після завершення терміну дії вони, як правило, не досягали своєї мети. }\end{array}$ \\
\hline $\begin{array}{c}2011 \\
{[9]}\end{array}$ & $\begin{array}{l}\text { Аудит ефективності використання коштів Держбюджету, виділених МОЗ на закупівлю ЛЗ, ВМП та } \\
\text { послуг для забезпечення хворих медичною допомогою, встановив, що МОЗ не впроваджено } \\
\text { ефективних управлінських рішень, спрямованих на вирішення пріоритетних потреб галузі О3. МО3 не } \\
\text { запровадило на державному рівні системи моніторингу цін на ЛЗ, що закуповуються за державні } \\
\text { кошти, та не забезпечило обгрунтованого планування обсягів видатків. }\end{array}$ \\
\hline $\begin{array}{c}2012 \\
{[10]}\end{array}$ & $\begin{array}{l}\text { Аудит ефективності використання коштів Держбюджету на виконання заходів Загальнодержавної } \\
\text { програми імунопрофілактики засвідчив, що МОЗ у } 2011 \text { не забезпечило ефективного використання } \\
\text { коштів. Незважаючи на те, що виконання заходів двох попередніх державних цільових програм не } \\
\text { дало запланованих результатів через відсутність відповідного фінансування та ефективних } \\
\text { управлінських рішень - МОЗ і надалі не забезпечило досягнення мети Програми у частині зниження } \\
\text { рівня захворюваності на інфекції, боротьба з якими проводиться засобами імунопрофілактики. } \\
\text { Планування МОЗ і Міністерством фінансів бюджетних призначень на закупівлю медичних } \\
\text { імунобіологічних препаратів було недостатньо спрямоване на досягнення показника Програми щодо } \\
\text { охоплення за рахунок коштів державного бюджету обов’язковими щепленнями на рівні не менше } 95 \% \\
\text { цільових груп населення. Визначені міністерствами в паспортах бюджетних програм на } 2011 \text { і } 2012 \\
\text { роки результативні показники передбачали закупівлю імунобіологічних препаратів в обсягах, що не } \\
\text { відповідали обрахованій регіонами потребі, та забезпечували щепленнями лише на рівні від } 50 \text { до } \\
97 \% \text { у У 2011-2012 рр. допущено списання вакцин на суму понад 2,6 млн грн, які були зіпсовані або } \\
\text { протерміновані (у т.ч. придбаних у } 2007 \text { р. на 2,4 млн грн). }\end{array}$ \\
\hline $\begin{array}{c}2013 \\
{[1]}\end{array}$ & $\begin{array}{l}\text { Основними причинами не освоєння коштів є неефективне управління ними, тривале проведення } \\
\text { тендерних закупівель. Невикористані направлені асигнування бюджетних програм МОЗ - } \\
\text { 762,6 млн грн, } 3 \text { них 81,9 \% не використано на забезпечення заходів окремих державних програм, } \\
\text { в т. ч. заходів з боротьби з епідеміями. }\end{array}$ \\
\hline
\end{tabular}

та їх використанням здійснює Рахункова палата (статті 95 і 98).

Отже, як свідчить аналіз висновків Рахункової палати (табл. 1), МО3 традиційно за різних Урядів та скликань ВР мало тенденцію до неефективного використання бюджетних коштів для покриття Програми імунопрофілактики, а не лише у 2014-2015 роках під час військових дій на Сході України.

ISSN 2312-0967. Фармацевтичний часопис. 2015. № 1 
Найповніші результати аудиту Рахункової палати з використання бюджетних коштів, виділених MOЗ на виконання заходів з імунопрофілактики населення, були оприлюднені лише у 2008 році. У цьому звіті наявна інформація про стан виконання заходів імунопрофілактики за 1997-2007 роки. Опісля таких детальних звітів, обґрунтованих абсолютними і відносними показниками, не знайдено. Водночас станом на 01.03.2015 р. відсутній звіт Рахункової палати за 2014 рік, а у звітах за 2009-2010 рр. немає інформації про видатки з Державного бюджету не лише на імунопрофілактику, а й на систему ОЗ загалом (рис. 2).

Однак у Законі України від 21.10.2009 р. № 1658-VI «Про затвердження Загальнодержавної програми імунопрофілактики та захисту на- селення від інфекційних хвороб на 2009-2015 роки» були заплановані вищі, ніж фактично отримані (рис. 2), обсяги фінансування закупівлі імунобіологічних препаратів з Державного бюджету (рис. 3) [2].

Якщо зіставити дані двох діаграм (рис. 2 і рис. 3), то виявляється дефіцит фінансування цієї Програми у наступних розмірах: 146,6 млн грн у 2011 р., 193,8 млн грн - у 2012 р., 226,4 млн грн - у 2013 р. Однак насправді дефіцит ще більший, оскільки у звітах Рахункової палати (рис. 2) представлені загальні витрати на забезпечення Загальнодержавної програми імунопрофілактики та захисту населення від інфекційних хвороб, яка, крім закупівлі імунобіологічних препаратів, передбачає також фінансування впровадження на державному рівні Сертифіка-

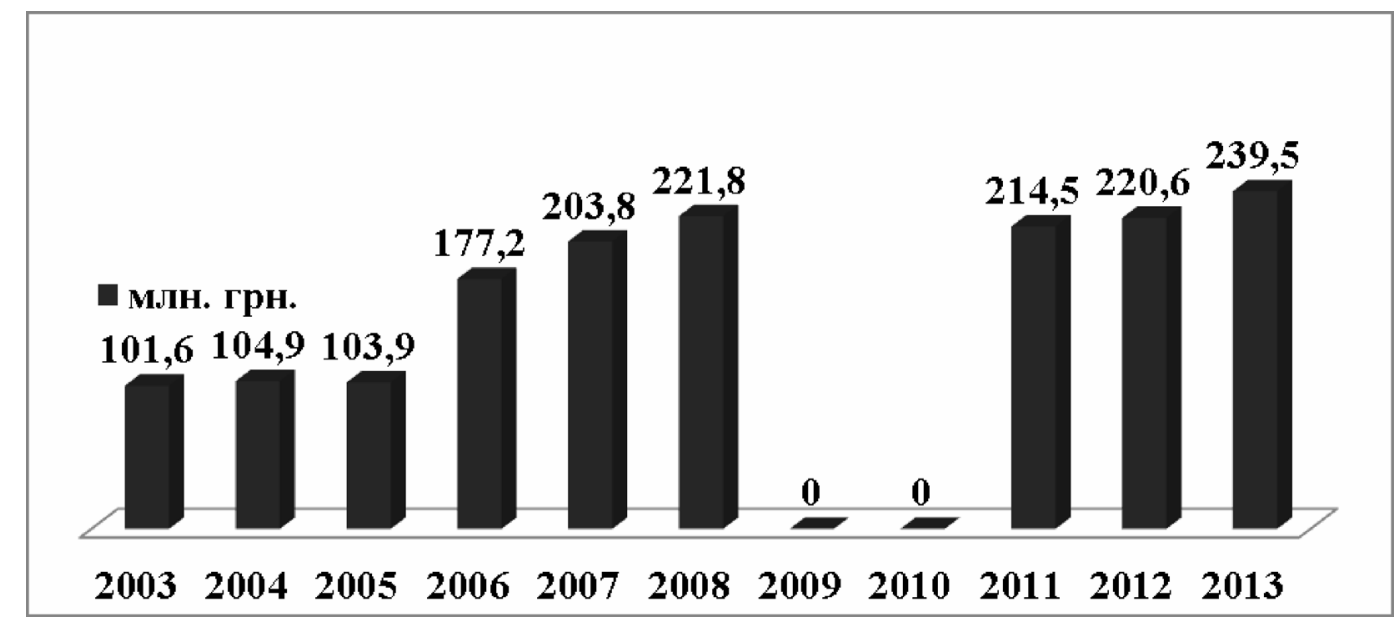

Примітка. 0 - відсутні дані у звітах Рахункової палати.

Рис. 2. Динаміка реального фінансування заходів з імунопрофілактики населення за рахунок коштів Державного бюджету України за Звітами Рахункової палати за 2003-2013 роки.

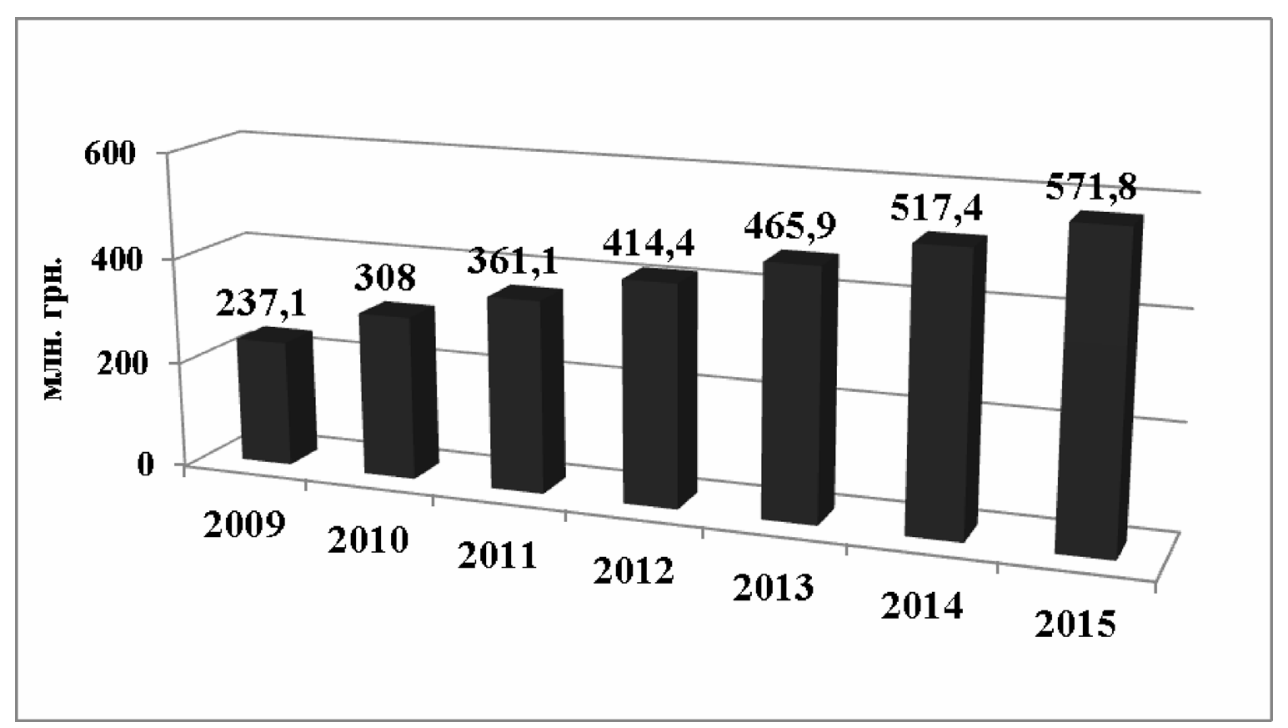

Рис. 3. Плановані обсяги забезпечень закупівлі імунобіологічних препаратів, включених до Календаря щеплень, за паспортом Програми імунопрофілактики на 2009 - 2015 рр. [2].

ISSN 2312-0967. Pharmaceutical review. 2015. № 1 
Організація роботи аптечних підприємств

Organization of pharmaceutical structures' work

та щеплень громадянина України, налагодження сучасної лабораторної діагностики інфекційних захворювань, створення системи «холодового ланцюга» під час транспортування, зберігання і використання вакцин, удосконалення підготовки фахівців з імунопрофілактики, що беруть участь у здійсненні заходів на етапах планування, організації, проведення контролю якості імунобіологічних препаратів, а дані, представлені на рисунку 3, стосуються лише фінансування власне закупівлі імунобіологічних препаратів. I це ще до дефіциту Державного бюджету 20142015 років, спричиненого насамперед військовою агресією Російської Федерації!

Проте у звітах МО3 у 2008-2009 роках продовжували фігурувати благополучні цифри: від 80 до 95 \% населення охоплено вакцинацією проти різних інфекцій. Водночас за аналізом інших джерел літератури (здебільшого виступів чи критичних заміток у пресі фахівців) нами побудовано криву з іншими даними (рис. 4) [4, 18, 15, 20].

Дані щодо рівня охоплення профілактичними щепленнями до 2007 року включно отримані зі звіту Рахункової палати за 2008 рік, а після 2007 року - за даними публічних фахових джерел. Так, на слуханнях у Комітеті Верховної Ради 3 питань охорони здоров'я вперше (березень 2011 р.) представники МОЗ озвучили близькі до реальності цифри охоплення вакцинацією. При цьому в окремих регіонах картина була просто катастрофічною: у Донецькій області 2 дози вакцини проти кору, епідемічного паротиту, краснухи отримали 20,4 \% дітей віком шести років, у Сумській та Житомирській областях 4 дози АаКДС-вакцини отримали 19,1 та 22,5 \% півтора- та однорічних дітей відповідно. За іншими даними МОЗ України, починаючи з 2008 року значна кількість дітей не була забезпечена достатньою кількістю вакцин [4].

Однак найкритичнішою ситуація із забезпечення вакцинами проти керованих інфекцій стала у 2014 році, адже деякі вакцини відсутні взагалі. За словами директора ГО «Імунний щит нації» Н. Винник, діапазон охоплення вакцинацією населення в 2014 р. варіював від 15 до 49 \% залежно від інфекційного захворювання [17]. При цьому в нашій державі щорічно народжується близько 500 тис. дітей, що означає постійну потребу в наявності достатньої кількості вакцин для проведення обов'язкового щеплення дітей 1 року життя. Окрім того, необхідно забезпечити потреби всіх малюків, які не були щеплені упродовж останніх 7 років. У цілому, державі для забезпечення 100 \% вакцинацією всіх новонароджених необхідно 10,8 млн доз різних вакцин. У грошовому виразі це становить від 20 до 23 млн дол. США [5].

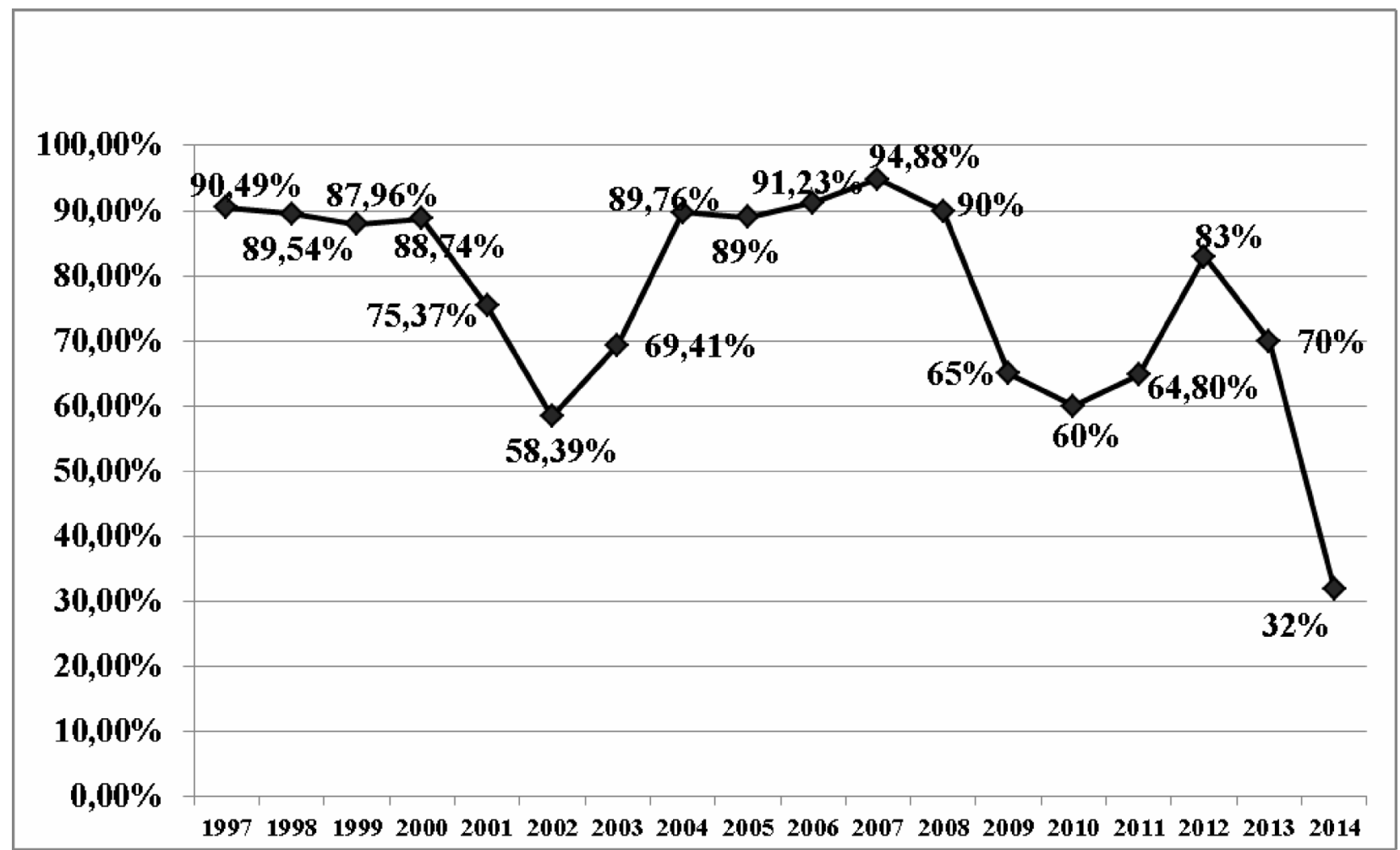

Рис. 4. Динаміка рівня охоплення населення України щепленнями проти керованих інфекційних хвороб відповідно до Календаря щеплень.

ISSN 2312-0967. Фармацевтичний часопис. 2015. № 1 
Організація роботи аптечних підприємств Organization of pharmaceutical structures' work

А відповідно до вже згаданої Коаліційної угоди у 2015 році державні закупівлі ЛЗ і вакцин повинні здійснюватись через міжнародні організації - ВООЗ і ЮНІСЕФ. Це включає електронізацію процесу, прямі закупівлі безпосередньо у виробника. При цьому Уряд укладає договори на закупівлю вакцин з міжнародними організаціями, а ті здійснюють закупівлю від його імені, що, за даними країн з аналогічною схемою, веде до зниження ціни на 30 \%. Ця практика застосовувалася у більш ніж 100 країнах Азії, Африки, Східної Європи та Південної Америки у перехідний період запровадження реформ [5, 14, 17].

Однак станом на 01.03.2015 року залишається відсутня можливість передачі бюджетних коштів будь-яким третім особам, у тому числі і міжнародним організаціям та фондам. Тому у ВР було зареєстровано законопроекти: № 2150 «Про внесення змін до деяких законодавчих актів України (щодо забезпечення своєчасного доступу пацієнтів до необхідних ЛЗ шляхом здійснення державних закупівель із залученням міжнародних закупівельних організацій)» та № 2151 «Про внесення зміни до Податкового кодексу України (щодо звільнення від оподаткування податком на додану вартість операцій 3 ввезення та постачання лікарських засобів)» [5].

Централізовано закуповує вакцини більшість країн. Дуже популярні в Європі закупівлі вакцин за так званими рамковими угодами, коли закупівля вакцин проводиться терміном на 3-5 років. Виробник, маючи таке довготривале замовлення, захищений від ризиків і планує свої потужності, оскільки процес виготовлення вакцини становить близько 6 місяців [17, 18].

Із зареєстрованих на сьогодні в Україні 15 вакцин ЮНІСЕФ може завезти тільки 4. При цьому, якби відповідний закон було прийнято наприкінці 2014 року, то Україна змогла б заощадити по 1,5 млн дол. на кожному лоті. Перші закупівлі вакцин через ЮНІСЕФ та фонди ООН можна буде зробити вже через 1,5 міс. після прийняття відповідних законів Верховною Радою України [5].

Тому як науковцям, практикуючим лікарям i провізорам, так і суспільству у цілому необхідно докласти зусиль для контролю за виконанням задекларованих намірів щодо забезпечення вакцинопрофілактики населення України. На сайті МОЗ Великої Британії написано [18]: «Вакцинація є другим найбільш ефективним медичним втручанням держави в життя суспільства після чистої води, що направлена на збереження життя в усьому світі».

Висновки. Питання вакцинопрофілактики інфекційних хвороб повинно бути стратегічним за будь-яких суспільно-політичних обставин життя країни. Однак, як виявив проведений аналіз стану фінансування як системи ОЗ України загалом, так і її складової - системи імунопрофілактики, в Україні традиційно спостерігався дефіцит коштів поряд із низькою ефективністю витрат. Така тенденція мала місце не лише у поточний час військового конфлікту, а й стала невтішною практикою. Так, відсоток фінансування витрат на систему ОЗ з Державного бюджету традиційно був біля позначки 3,7 \% від ВВП та покривав близько 57 \% загального обсягу потреб населення.

Водночас аналіз матеріалів аудитів Рахункової палати України свідчить, що прогнозовані обсяги фінансування 3 Державного бюджету Програми імунопрофілактики на 2009 - 2015 рр. розходилися 3 реальними асигнуваннями у 2011-2013 рр. у середньому на 45,3 \%. Поряд 3 цим, за висновками Рахункової палати за 20072013 роки, МОЗ традиційно не забезпечує ефективного використання навіть наявних коштів Державного бюджету. Це призвело до того, що не вдалося знизити рівень захворюваності на інфекції, боротьба з якими проводиться засобами імунопрофілактики. Про це, насамперед, свідчить діапазон охоплення вакцинацією населення в 2014 р. на рівні від 15 до 49 \% залежно від інфекційного захворювання при рекомендаціях ВООЗ - 95 \%.

Тому реформа фінансування Програми імунопрофілактики повинна передусім зосередитися на підвищенні ефективності витрат, зокрема, через реформування сектора закупівель, які пропонується на зразок багатьох країн проводити за посередництвом ВООЗ і ЮНІСЕФ через «рамкові» (безпосередні довготривалі) угоди 3 постачальниками вакцин. А на це вже потрібна не декларативна, а реальна політична воля.

\section{Література}

1. Висновок щодо виконання Державного бюджету України за перше півріччя 2013 року. - К. : Рахункова палата України, 2013 [Електронний ресурс]. - Режим доступу : URL : http://www.ac-rada.gov.ua/control/main/ uk/publish/ category/32826. - Назва з екрану.

2. Закон України № 1658-VI від 21.10.2009 р. «Про

затвердження Загальнодержавної програми імунопрофілактики та захисту населення від інфекційних хвороб на 2009-2015 роки» [Електронний ресурс]. Режим доступу : URL : http://zakon2.rada.gov.ua/laws/ show/1658-17. - Назва з екрану.

3. Закон України № 645-14 від 05.12.2012 р. «Про за-

ISSN 2312-0967. Pharmaceutical review. 2015. № 1 
Організація роботи аптечних підприємств

Organization of pharmaceutical structures' work

хист населення від інфекційних хвороб» [Електронний ресурс]. - Режим доступу : URL : http:// zakon4.rada.gov.ua/laws/show/ 5460-17. - Назва з екрану.

4. Законодавча база щодо проведення імунопрофілактики потребує нагального перегляду [Електронний ресурс]. - Режим доступу : URL : http://www.umj.com.ua /article/10590/. - Назва з екрану.

5. Закупівля вакцин через міжнародні організації залежить від рішення Верховної Ради України - Олександр Квіташвілі [Електронний ресурс]. - Режим доступу : URL : http://www.apteka.ua/article/325056. - Haзва з екрану.

6. Звіт про результати аудиту використання коштів державного бюджету, виділених МОЗ на виконання заходів з імунопрофілактики населення. - Київ. : Рахункова палата України, 2008 [Електронний ресурс]. - Режим доступу : URL : http://www.ac-rada.gov.ua/ control/main/uk/publish/article/1143621. - Назва з екрану.

7. Звіт Рахункової палати України за 2008 рік. - К. : Рахункова палата України, 2009 [Електронний ресурс]. - Режим доступу : URL : http://www.ac-rada.gov.ua/ control/main/uk/publish/article/1497434. - Назва з екрану.

8. Звіт Рахункової палати України за 2010 рік. - К. : Рахункова палата України, 2011 [Електронний ресурс]. - Режим доступу : URL : http://www.ac-rada.gov.ua/ doccatalog/document/16741918/Zvit_2010.pdf. - Назва з екрану.

9. Звіт Рахункової палати України за 2011 рік. - К. : Рахункова палата України, 2012 [Електронний ресурс]. - Режим доступу : URL : http://www.ac-rada.gov.ua/ doccatalog/document/16740480/Zvit_2011.pdf. - Назва з екрану.

10. Звіт Рахункової палати України за 2012 рік. - К. : Рахункова палата України, 2013 [Електронний ресурс]. - Режим доступу : URL : http://www.ac-rada.gov.ua/ control/main/uk/publish/category/32826. - Назва з екрану.

11. Котвіцька А. А. Вивчення методології фармакоекономічних досліджень вакцинопрофілактики / А. А. Котвіцька, О. В. Кононенко // Матеріали VI наук.- практ. конф. «Фармакоекономіка в Україні: стан та перспективи розвитку». Харків : Видавництво НФаУ, 2013. -206 c.

12. Про удосконалення проведення профілактичних щеплень в Україні [Електронний ресурс]: наказ МОЗ України № 551 від 11.08.2014 р. - Режим доступу : URL : www.apteka.ua/article/311737. - Назва з екрану. 13. Немченко А. С. Дослідження стану надання фармацевтичної допомоги хворим за державними цільовими програмами «Туберкульоз», «СНІД», «Онкологія» та «Дитяча онкологія» / А. С. Немченко, Г. Л. Панфілова, Ю. В. Корж // Управління, економіка та забезпечення якості в фармації. - 2009. - № 3 (5). C. 65-71.

14. Проект Національної стратегії побудови нової системи охорони здоров'я в Україні на період 2015-2025 [Електронний ресурс]. - Режим доступу : URL : http:// www.apteka.ua/article/315522. - Назва з екрану.

15. Рахункова палата України: програма з імунопрофілактики не впроваджується МОЗ на належному рівні [Електронний ресурс]. - Режим доступу : URL : http:// www.apteka.ua/article/189699. - Назва з екрану.

16. Реформа фінансування охорони здоров'я України. Замість впровадження моделей - вирішення нагальних проблем [Електронний ресурс]. - Режим доступу : URL : http://www.apteka.ua/article/35349. - Назва з екрану.

17. Ситуація з вакцинацією в Україні критична - достатньої кількості вакцин немає [Електронний ресурс]. - Режим доступу : URL : http://www.apteka.ua/article/ 323029. - Назва з екрану.

18. Українці можуть не помирати [Електронний ресурс]. - Режим доступу : URL : http://www.vz.kiev.ua/ru/ ukra\%D1\%97nci-mozhut-ne-pomirati/ - Назва з екрану. 19. Феденько С. М. Фінансове забезпечення медичних послуг у системі бюджетного фінансування / С. М. Феденько // Актуальні проблеми розвитку економіки регіону: за ред. І. Г. Ткачук. - Івано-Франківськ : Вид-во Прикарп. нац. ун. ім. Василя Стефаника, 2013. - Вип. 9, - Т. 2. - 335 с.

20. Щеплення - українська рулетка [Електронний ресурс]. - Режим доступу : URL :www.vz.kiev.ua/ru/. Назва з екрану.

\section{ИССЛЕДОВАНИЕ ДИНАМИКИ ФИНАНСИРОВАНИЯ ПРОГРАММ ИММУНОПРОФИЛАКТИКИ В УКРАИНЕ}

\section{И. О. Федяк, И. И. Иванюлик}

Ивано-Франковский национальный медицинский университет

Резюме: 2015 год - год завершения реализации Общегосударственной программы иммунопрофилактики и защиты населения от инфекционных болезней на 2009-2015 гг. Целью принятия Программы было обеспечение эпидемического благополучия населения путем снижения уровня заболеваемости инфекциями, борьба с которыми проводится средствами иммунопрофилактики. Однако объективные и субъективные причины политико-экономических обстоятельств сегодняшнего дня уже привели к тому, что Программа не выполняется. Состояние ее реализации в части финансирования и, соответственно, охват прививками населения Украины на начало последнего года действия Программы даже не достигает уровня 50 \%. В статье представлена динамика как финансирование системы здравоохранения Украины в целом, так и Программы иммунопрофилактики в

ISSN 2312-0967. Фармацевтичний часопис. 2015. № 1 
частности, а также процента охвата прививками детей за период реализации действующей и предыдущей Программы иммунопрофилактики.

Ключевые слова: программа иммунопрофилактики, объем финансирования системы здравоохранения Украины, процент охвата прививками населения.

\title{
RESEARCH OF DYNAMICS FOR IMPLEMENTATION THE PROGRAM OF IMMUNIZATION PREVENTION IN UKRAINE
}

\author{
I. O. Fedyak, I. I. Ivanyulyk \\ Ivano-Frankivsk National Medical University
}

Summary: 2015 is the year of the completion of implementation the National program on immunization and population protection from infectious diseases during 2009-2015. The purpose for adoption of the Program was to provide epidemiological population welfare by reducing the incidence of infections, the combat of which is held by immunization devices. However, the objective and subjective reasons of political-economic realities nowadays have already led to the fact that the Program is not running. The status of its implementation in terms of financing and, accordingly, the coverage of the child population vaccination of Ukraine at the beginning of the last year is not even reaches the level of $50 \%$. The article presents the dynamics of as the financing of the health care system of Ukraine in general as Program of immunization prevention particularly and also the percentage of vaccination coverage of children over the period of implementation as current as previous Program of immunization prevention according to public sources.

Key words: Program of immunization prevention, funding of the Health Care System of Ukraine, percentage of coverage vaccination of the population. 